\title{
Profil Kecukupan Asupan Makanan pada Rawat Inap
}

\author{
Julius Anzar, Bagus Pratignyo, M Nazir \\ Departemen Ilmu Kesehatan Anak Fakultas Kedokteran Universitas Sriwijaya RS Dr. Mohammad \\ Hoesin, Palembang
}

\begin{abstract}
Latar belakang. Kekurangan Jumlah asupan makanan pasien rawat inap sering kali ditemukan.
Tujuan. Mengetahui profil kecukupan asupan makanan pada pasien anak rawat inap.

Metode. Penelitian cross sectional dilakukan November 2011- Januari 2012 pada pasien anak rawat inap di RSUP Dr. Mohammad Hoesin, Palembang. Sampel dipilih secara consecutive dengan kriteria usia >1-10 tahun, dirawat $>24$ jam, tidak menderita sakit kritis, bukan gizi buruk, tidak terdapat kontraindikasi makan per oral, tidak terdapat masa atau asites diberikan asupan nutrisi berdasarkan buku rekomendasi IDAI tentang asuhan nutrisi pediatrik. Data asupan makan dihitung setelah perawatan 3 hari rawat dan data dianalisis dengan uji Fisher. Asupan dinyatakan tidak cukup apabila asupan rata-rata energi dan protein 3 hari pertama $<80 \%$ kebutuhan.

Hasil. Didapatkan 105 pasien yang diteliti, terbanyak usia 6-10 (59\%) tahun, jenis kelamin perempuan (52\%), status gizi baik (52\%). Umur 1-5 tahun, asupan energi tidak cukup 27,9\%; asupan protein tidak cukup 34,9\%. Umur 6-10 tahun, asupan energi tidak cukup 50\%; asupan protein tidak cukup 37,1\%. Anak laki-laki, asupan energi tidak cukup 36\%; asupan protein tidak cukup 15 30\%. Anak perempuan, asupan energi tidak cukup 45,5\%; asupan protein tidak cukup 41,8\%. Gizi baik, asupan energi tidak cukup $38,2 \%$; asupan protein tidak cukup $36,4 \%$. Gizi kurang, asupan energi tidak cukup $44 \%$; asupan protein tidak cukup $36 \%$.

Kesimpulan. Ketidakcukupan energi dan protein lebih banyak dialami oleh perempuan dan kelompok umur 6-10 tahun. Sari Pediatri 2013;14(6):351-6.
\end{abstract}

Kata kunci: asupan, energi, dan protein

\footnotetext{
Alamat korespondensi:

Dr. Julius Anzar, Sp.A. Departemen Ilmu Kesehatan Anak Fakultas Kedokteran Universitas Sriwijaya RS Dr Mohammad Hoesin, Palembang. Jl. Jendral Sudirman KM 3,5. Telp. (0711) 372832, (0711) 321635. E-mail: julius_anzar@idai.or.id
}

$\mathrm{M}$ alnutrisi sampai saat ini masih menjadi permasalahan nasional. Oleh karena itu, permasalahan malnutrisi dan kesehatan anak perlu dikaji secara mendalam dan terintegrasi sehingga diperoleh cara pemecahan masalah malnutrisi yang tepat. Salah satu permasalahan malnutrisi pada anak adalah malnutrisi rumah sakit (hospital malnutrition). 
Malnutrisi rumah sakit (MRS) adalah suatu keadaan penurunan berat badan pasien yang sedang menjalani perawatan dalam jangka waktu tertentu tanpa sebab yang jelas. ${ }^{1}$ Sebanyak $6,1 \%-51,6 \%$ anak telah mengalami hospital malnutrition. ${ }^{1,3-5}$ Salah satu penyebab MRS adalah pelaksanaan asuhan nutrisi yang belum dilakukan secara baik dan benar. Pada tahun 2011, Ikatan Dokter Anak Indonesia (IDAI) telah mengeluarkan rekomendasi asuhan nutrisi pediatrik (ANP) untuk mencegah MRS dengan melakukan dengan beberapa langkah. Langkahlangkah tersebut secara berurutan, yaitu assessment (penilaian), penentuan jumlah kebutuhan makanan yang akan diberikan kepada anak, penentuan cara pemberian makanan, penentuan jenis makanan serta pemantauan dan evaluasi. ${ }^{6}$

Apabila tidak terdapat kontraindikasi, pemberian nutrisi melalui oral merupakan pilihan utama cara pemberian makan pada ANP. Namun, jumlah asupan makanan peroral sangat bergantung kepada selera makan anak. Seringkali anak mengalami penurunan selera makan ketika sakit dan dirawat di rumah sakit. Hal tersebut akan menyebabkan asupan makanan yang dimakan berkurang. Penurunan selera makan anak yang sakit disebabkan oleh berbagai hal, antara lain faktor penyakit yang diderita, perubahan suasana, dan perubahan bentuk makanan.

Penelitian kami dilakukan untuk mengetahui gambaran rata-rata asupan energi dan asupan protein tiga hari pertama dirawat di rumah sakit dibandingkan dengan rata-rata asupan energi dan protein (asupan awal) saat dirawat di rumah sakit. Dengan mengetahui besarnya jumlah asupan makanan, maka akan dapat diperkirakan jumlah kekurangannya sehingga kita dapat melakukan upaya untuk mencukupkan asupan sesuai dengan kebutuhan anak tersebut.

\section{Metode}

Penelitian cross sectional dilakukan mulai bulan November 2011-Januari 2012 pada pasien yang dirawat di ruang perawatan anak RSUP Dr. Mohammad Hoesin, Palembang. Pasien dengan gizi buruk dieksklusi dari penelitian ini. Subjek penelitain adalah anak usia $>1-10$ tahun, dirawat $>24$ jam dan minimal dirawat inap 3 hari, pasien tidak sakit kritis, bukan gizi buruk, tidak terdapat kontraindikasi makan per oral, tidak terdapat massa atau ascites. Jumlah subjek penelitian
105 orang, subjek yang memenuhi kriteria inklusi dibagi menjadi 2 kelompok, yaitu kelompok dengan asupan energi dan protein cukup dan kelompok asupan energi dan protein tidak cukup. Pengelompokan tersebut berdasarkan rata-rata asupan energi dan protein 3 hari pertama. Subjek termasuk ke dalam tidak cukup apabila asupan rata-rata energi dan protein 3 hari pertama $<80 \%$ kebutuhan, dan kelompok asupan asupan rata-rata energi dan protein cukup apabila $\geq 80 \%$ kebutuhan. Data asupan makanan diperoleh melalui food recall 24 jam selama 3 hari. Data yang telah dicek kelengkapannya dimasukkan ke dalam komputer dan dianalisis dengan menggunakan SPSS 15.

\section{Hasil}

Berdasarkan Tabel 1, tidak terdapat perbedaan bermakna antara jenis kelamin dengan usia, pendidikan ayah, pendidikan ibu, pekerjaan ayah, pekerjaan ibu, penghasilan orang tua dan status gizi $(p>0,05)$.

Berdasarkan kelompok umur subyek, kelompok 1-5 tahun dan 6-10 tahun, asupan energi dan protein yang tidak cukup, cukup besar berkisar 27,9\%- 50\%. Untuk jenis kelamin laki-laki ketidakcukupan energi dan protein berturut-turut $36 \%$ dan $30 \%$, lalu jenis kelamin perempuan $45,5 \%$ dan $41,8 \%$. Kami mendapatkan, bahwa anak gizi baik yang mengalami ketidakcukupan asupan energi dan protein ketika masuk rumah sakit cukup tinggi, yaitu 38,2\% dan $36,4 \%$ dan pada anak gizi kurang 44\% dan 36\% (Tabel 2).

\section{Pembahasan}

Berdasarkan kelompok umur subjek, kelompok 1-5 dan 6-10 tahun, asupan energi dan protein yang tidak cukup, cukup besar yaitu berkisar $27,9 \%-50 \%$. Hal tersebut menunjukkan bahwa potensi untuk terjadi malnutrisi rumah sakit cukup besar. Begitu juga penyebaran secara jenis kelamin, status gizi, maupun gejala klinis, asupan energi dan protein yang tidak cukup, cukup merata. Untuk jenis kelamin laki-laki, ketidakcukupan energi dan protein $36 \%$ dan $30 \%$, lalu jenis kelamin perempuan $45,5 \%$ dan $41,8 \%$. Itu menandakan bahwa ketidakcukupan asupan energi dan protein tidak banyak dipengaruhi oleh jenis kelamin. Status gizi yang baik tidak menjamin bahwa si anak 
Tabel 1. Karakteristik subjek $(\mathrm{n}=105)$

\begin{tabular}{|c|c|c|c|}
\hline & Laki-laki & Perempuan & $\mathrm{p}$ \\
\hline \multicolumn{4}{|l|}{ Usia (tahun) } \\
\hline $1-5$ & $22(51,8)$ & $21(48,8)$ & \multirow[t]{2}{*}{0.545} \\
\hline $6-10$ & $28(45,2)$ & $34(54,8)$ & \\
\hline \multicolumn{4}{|l|}{ Pendidikan ayah } \\
\hline SD & $10(37)$ & $17(63)$ & \multirow[t]{5}{*}{0,262} \\
\hline SMP & $9(45)$ & $11(55)$ & \\
\hline SMA & $19(46,3)$ & $22(53,71)$ & \\
\hline D III & $3(75)$ & $1(25)$ & \\
\hline S 1 & $9(69,2)$ & $4(30,8)$ & \\
\hline \multicolumn{3}{|l|}{ Pendidikan ibu } & \multirow[t]{6}{*}{0,392} \\
\hline SD & $19(50)$ & $19(50)$ & \\
\hline SMP & $10(55,6)$ & $8(44,4)$ & \\
\hline SMA & $12(34,3)$ & $23(65,7)$ & \\
\hline D III & $4(80)$ & $1(20)$ & \\
\hline S 1 & $5(55,6)$ & $4(44,4)$ & \\
\hline \multicolumn{4}{|l|}{ Pekerjaan ibu } \\
\hline Ibu rumah tangga & $37(50,7)$ & $36(49,3)$ & \multirow[t]{7}{*}{0,543} \\
\hline Buruh & $1(100)$ & $0(0)$ & \\
\hline Wiraswasta & $1(50)$ & $1(50)$ & \\
\hline Swasta & $2(40)$ & $360)$ & \\
\hline PNS & $3(60)$ & $2(40)$ & \\
\hline Guru & $1(33,3)$ & $2(60,7)$ & \\
\hline Petani & $5(31,21)$ & $11(66,8)$ & \\
\hline \multicolumn{4}{|c|}{ Penghasilan orang tua (juta) } \\
\hline$\leq 1,8$ & $33(49,3)$ & $34(50,7)$ & \multirow[t]{2}{*}{0.322} \\
\hline$\geq 1,8$ & $17(44,7)$ & $21(55,3)$ & \\
\hline \multicolumn{4}{|l|}{ Status gizi } \\
\hline Baik & $29(52,7)$ & $26(47,3)$ & \multirow[t]{2}{*}{0,262} \\
\hline Kurang & $21(42)$ & $29(58)$ & \\
\hline
\end{tabular}

mendapat asupan yang cukup selama dirawat di rumah sakit. Kami mendapatkan bahwa anak gizi baik yang masuk rumah sakit yang mengalami ketidakcukupan asupan energi dan protein cukup tinggi, yaitu 38,2\% dan 36,4\%. Walaupun persentase ketidakcukupan energi dan protein pada anak gizi kurang juga cukup tinggi, yaitu $44 \%$ dan 36\%. Angka tersebut akan menyebabkan tidak hanya malnutrisi rumah sakit tetapi juga dapat menurunkan status gizi dari gizi baik ke gizi kurang, bahkan ke gizi buruk. Keluhan pasien berupa demam, nyeri kepala, nyeri sendi, maupun gastrointestinal tampaknya cukup memengaruhi jumlah asupan makanan. Jadi, sebaiknya keluhan ini segera ditanggulangi sehingga asupan makanan dapat meningkat.

Status nutrisi merupakan salah satu faktor yang mempunyai peran penting dalam perjalanan suatu penyakit terlebih penyakit yang memerlukan perawatan inap. Usaha perbaikan dan pemeliharaan status nutrisi yang baik dapat mempercepat penyembuhan, mempersingkat perawatan yang berarti mengurangi biaya rawat secara bermakna. Beberapa laporan juga menunjukkan bahwa 30\% pasien yang dirawat inap sudah dalam keadaan malnutrisi saat masuk rumah sakit, dan keadaan ini dapat berlanjut menjadi lebih parah selama perawatan apabila tidak mendapat intervensi yang memadai baik intervensi nutrisi maupun medis untuk penyakit yang dideritanya. ${ }^{7}$ Anak yang menjalani rawat inap perlu mendapatkan perhatian serius dan perawatan secara multidisiplin. Salah satunya dengan melakukan asuhan nutrisi pediatrik (ANP) sehingga terjalin kerjasama multidisiplin dalam tim asuhan gizi rumah sakit. 
Tabel 2. Profil kecukupan asupan energi dan protein berdasarkan kelompok usia, jenis kelamin, status gizi, gejala klinis $(\mathrm{n}=105)$

\begin{tabular}{|c|c|c|c|c|}
\hline \multirow{2}{*}{ Karakteristik } & \multicolumn{2}{|c|}{ Energi } & \multicolumn{2}{|c|}{ Protein } \\
\hline & Cukup(n,\%) & Tidak cukup (n,\%) & Cukup(n,\%) & Tidak cukup(n,\%) \\
\hline \multicolumn{5}{|l|}{ Usia } \\
\hline $1-5$ & $31(72,1)$ & $12(27,9)$ & $28(65,1)$ & $15(34,9)$ \\
\hline $6-10$ & $31(50)$ & $31(50)$ & $39(62,9)$ & $23(37,1)$ \\
\hline \multicolumn{5}{|l|}{ Jenis kelamin } \\
\hline Laki-laki & $32(64)$ & $18(36)$ & $35(70)$ & $15(30)$ \\
\hline Perempuan & $30(54, .5)$ & $25(45,5)$ & $32(58,2)$ & $23(41,8)$ \\
\hline \multicolumn{5}{|l|}{ Status gizi } \\
\hline Baik & $34(61,4)$ & $21(38,2)$ & $35(63,6)$ & $20(36,4)$ \\
\hline Kurang & $28(56)$ & $22(44)$ & $32(64)$ & $18(36)$ \\
\hline \multicolumn{5}{|l|}{ Demam } \\
\hline Tidak ada & $11(73,3)$ & $4(26,7)$ & $13(86,7)$ & $2(13,3)$ \\
\hline Ada & $51(56,7)$ & $39(43,3)$ & $54(60)$ & $36(40)$ \\
\hline \multicolumn{5}{|c|}{ Gejala gastrointestinal } \\
\hline Tidak ada & $43(64,20$ & $24(35,8)$ & $45(67,22)$ & $22(32,8)$ \\
\hline Ada & $19(50)$ & $19(50)$ & $22(57,9)$ & $16(42,1)$ \\
\hline \multicolumn{5}{|l|}{ Nyeri kepala } \\
\hline Tidak ada & $62(62)$ & $38(38)$ & $65(65)$ & $35(35)$ \\
\hline Ada & 0 & $5(100)$ & $2(40)$ & $3(60)$ \\
\hline \multicolumn{5}{|c|}{ Nyeri persendian } \\
\hline Tidak ada & $61(59,8)$ & $41(40,2)$ & $65(63,7)$ & $37(36,3)$ \\
\hline Ada & $1(33,3)$ & $2(66,7)$ & $2(66,7)$ & $1(33,3)$ \\
\hline
\end{tabular}

Sermet-Gaudelus $\mathrm{dkk}^{8}$ melaporkan pada penelitiannya bahwa terjadi malnutrisi rumah sakit pada anak yang di rawat inap di rumah sakit > 48 jam, 57\% di antaranya laki- laki dengan umur terbanyak pada kisaran umur $>6(25 \%)$ tahun, serta memiliki status gizi baik (41\%). Sementara itu, Campanozzi dkk, ${ }^{9}$ melaporkan bahwa karakteristik anak-anak yang dirawat inap $>72$ jam yang mengalami malnutrisi rawat inap memiliki kisaran umur $>6$ tahun $(23,8 \%)$, dengan status gizinya BMI $Z$-score $-2 /+2(78,1 \%)$ serta diagnosis penyakit yang banyak ditemukan adalah penyakit respirologi $(37,7 \%)$, dan gejala gastrointestinal (26,4\%).

Menurut Departemen Kesehatan RI (2007), ${ }^{10}$ pemenuhan kebutuhan nutrisi anak yang dirawat seringkali tidak mudah dan peran tim asuhan nutrisi menjadi sangat penting dengan melakukan proses asuhan nutrisi. Asuhan nutrisi pediatrik yang belum sempurna dapat disebabkan oleh beberapa hal, antara lain kurangnya kesadaran dari dokter, kurangnya pengetahuan, ketrampilan dan strategi penanganan terapi nutrisi, tingginya biaya dukungan nutrisi tersebut, dan karena komplikasi yang terjadi akibat dukungan nutrisi tersebut. Agar ANP dapat berjalan sempurna dilakukan lima kegiatan yang berurutan dan berulang serta memerlukan kerja sama dari berbagai tenaga profesional. Lima kegiatan yang dimaksud adalah membuat diagnosis masalah nutrisi, menentukan kebutuhan nutrisi (requirement), memilih cara pemberian zat gizi, memilih bentuk sediaan zat gizi, dan melakukan evaluasi/pengkajian respon. ${ }^{6}$

Pada beberapa penelitian sebelumnya dilaporkan bahwa prevalensi terjadinya MRS pada pasien anak rawat-inap cukup tinggi, yaitu antara 6,1\%-51,6\% dan insidennya meningkat pada pasien yang dirawat di rumah sakit lebih dari dua atau tiga minggu. ${ }^{2,3}$ Penelitian di Departemen Ilmu Kesehatan Anak Fakultas Kedokteran Universitas Indonesia/Rumah Sakit Ciptomangunkusumo, Jakarta didapatkan hasil bahwa 50\%-60\% jumlah pasien anak yang menderita malnutrisi rumah sakit meningkat sesudah perawatan 
14 hari. ${ }^{4,5}$ Penelitian di Departemen Ilmu Kesehatan Anak Fakultas Kedokteran Universitas Sriwijaya/ Rumah sakit Mohammad Hoesin, Palembang didapatkan hasil bahwa jumlah pasien anak mulai menderita malnutrisi rumah sakit setelah 3 hari perawatan dan meningkat sesudah 7 hari perawatan dengan angka kejadian MRS 37\%. ${ }^{12} \mathrm{Hal}$ tersebut sesuai dengan penelitian Campanozzi $\mathrm{dkk}^{9}$ yang menemukan bahwa penurunan berat badan paling banyak terjadi setelah 72 jam perawatan di rumah sakit.

Hal ini sejalan dengan yang dilaporkan, malnutrisi rumah sakit dapat terjadi karena beberapa sebab, antara lain kondisi penyakit yang sedang diderita oleh pasien itu sendiri, asupan makanan yang tidak adekuat, stres dari manifestasi klinik yang timbul, ketakutan pasien akan tindakan medis yang dilakukan, atau ketika berhadapan dengan dokter, paramedik, dan lain-lain. ${ }^{12,13}$ Selain itu, penyakit yang menyerang daerah wajah, mulut, faring, atau esofagus juga dapat memberikan dampak langsung terhadap status nutrisi seseorang karena gangguan pada proses makan. Anak yang pernah mengalami penggunaan prosedur invasif pada mulut, seperti suction, nasogastric tube (NGT), atau endotracheal tube (ETT) dapat menjadi intoleran terhadap suatu stimulasi di daerah mulut, mereka merasa proses makan merupakan suatu kondisi yang mengancam. Penyakit kronis umumnya akan memengaruhi status nutrisi seorang anak, seperti penyakit jantung bawaan, penyakit kronis (paru, hati, ginjal, dan saluran cerna), HIV/AIDS, trauma/luka bakar, keganasan dan kelainan metabolisme bawaan. Malnutrisi rumah sakit dapat pula terjadi secara iatrogenik, yaitu malnutrisi yang berkaitan dengan suatu tindakan pengobatan seperti radiasi, kemoterapi ataupun pemberian antibiotik

Menurut Baker, ${ }^{14}$ pemberian makanan secara oral dapat dilaksanakan pada sebagian besar pasien dalam pelayanan gizi rumah sakit, jika tidak, pemberian makanan cair personde bisa dilakukan. Tetapi, apabila cara tersebut tidak memungkinkan atau tidak dapat memenuhi zat gizi secara lengkap, maka dilaksanakan pemberian dukungan nutrisi enteral dan parenteral.

Penurunan asupan makanan yang berakibat MRS perlu diwaspadai karena memengaruhi perjalanan dan proses penyembuhan penyakit, sehingga dapat berakibat bertambah lama masa rawat yang berdampak pada biaya perawatan yang meningkat. Oleh karena itu, langkah strategis untuk mengatasi MRS adalah melakukan ANP. Diperlukan juga optimalisasi kerjasama dalam tim asuhan gizi rumah sakit untuk pelaksanaan ANP.

Keterbatasan pada penelitian kami adalah rentang umur yang lebar sehingga kemampuan makan pada berbagai usia yang berbeda mungkin akan berpengaruh terhadap asupan makanan.

\section{Kesimpulan}

Berdasarkan hasil penelitian kami dapat ditarik kesimpulan, yaitu rata-rata asupan energi dan protein selama di rumah sakit berhubungan dengan rata-rata asupan tiga hari pertama dirawat di rumah sakit. Pasien dengan asupan energi tidak cukup selama dirumah sakit mempunyai risiko lebih besar untuk malnutrisi dibandingkan dengan pasien dengan asupan energi cukup. Bertitik tolak dari hasil penelitian kami, disarankan perlunya meningkatkan asupan makanan pasien selama di rumah sakit terutama dari sumber energi untuk mengurangi kejadian malnutrisi di rumah sakit. Asupan makanan ini dapat ditingkatkan apabila terdapat kerjasama antar tenaga medis di rumah sakit.

\section{Daftar pustaka}

1. Nasar S.S. Nutrisi pediatrik suatu subspesialisasi tersendiri. Dalam: Sjarif DR, Lestari ED, Mexitalia M, Nasar SS, penyunting. Buku ajar nutrisi pediatrik dan penyakit metabolik. Edisi 1. Jakarta: IDAI; 2011. h. $1-5$.

2. Rocha G.A, Rocha E.J, and Martins C.V. The effects of hospitalization on the nutritional status of children. Journal de Pediatrica 2006;82:70-4.

3. Pawellek I. Dokoupil K., dan Koletzko B. Prevalence of malnutrition in paediatric hospital patients. Am J Clin Nutr 2008;27:72-6.

4. Ginting R.U. Perubahan status nutrisi pasien rawat inap di bagian ilmu kesehatan anak FKUI - RSCM (Tesis). Jakarta: Fakultas Kedokteran Universitas Indonesia, 2000.

5. Tienboon P. Nutrition problem of hospitalized children in a developing country: Thailand. Asia Pasific J Clin Nutr 2002;11:258-62.

6. Ikatan Dokter Anak Indonesia. Rekomendasi IDAI asuhan nutrisi pediatrik. Jakarta: IDAI; 2011.

7. Sidiartha L.G.I. Insidens malnutrisi rawat inap pada anak 
balita di rumah sakit umum pusat Sanglah Denpasar. Sari Pediatri 2008;9:381-5.

8. Sermet-Gaudelus. Simple pediatric nutritional risk score to identify children at risk of malnutrition. Am J Clin Nutr 2000;72:64-70.

9. Campanozzi A., Rutigliano I, Russo M. Risk factors and outcome of hospital acquired malnutrition in children. JPGN 2004;39:505-6.

10. Departemen Kesehatan Republik Indonesia. Skrining malnutrisi pada anak yang dirawat di rumah sakit. Jakarta: Departemen Kesehatan Republik Indonesia; 2007.

11. Anzar J, Nazir. Hospital malnutrition in Moh. Hoesin Hospital. Dalam: Lubis B, Ali M, Yanni NG, Trisnawati
Y, Ramayani OR, Irsa L, penyunting. Prosiding dari pertemuan ilmiah tahunan ilmu kesehatan anak; Medan, Indonesia. 2010.

12. Chatoor I, penyunting. Post traumatic feeding disorder. Dalam: Diagnosis and treatment of feeding disorder in infants, toddlers and young children. Washington DC: Zero to Three; 2000. h.85-101.

13. Stratton R.J dan Elia M. Deprivation linked to malnutrition risk and mortality. Brit J Nutr 2006;96:8706.

14. Baker S. Protein-energy malnutrition in the hospitalized patient. Dalam: Nutrition in pediatrics basic science and clinical applications. Edisi ketiga. London: BC Decker Inc; 2003. h. 910-16. 